\title{
Urban Environmental History of an Anatolian City: Destroying the Riverscape of Kayseri
}

\author{
By Methiye Gul Coteli*
}

Interrelations with waters and rivers have played an important role in the formation of early settlements and city development. The long history of extensive human interventions in rivers shows that the relationship between the city and the natural environment has been a circular one. Urban developers have often reshaped the natural environment and creating huge areas of made land. They have constructed a built environment and altered urban riverscapes according to human needs, aesthetic ideals and technical options. The protection of heritage is rarely a problem because of the existing legislation. However, there is no restriction about the alteration of the urban riverscape. Hence, the most pressing problem is how easily a city's riverscape, which is a historical resource, can be changed. This paper aimed to assess the relation of integration between a city and its river and to describe the loss of the riverscape, which is a part of the cultural landscape, due to urban expansion in an Anatolian city, Kayseri, between 1882 and 2012. To address this transformation issue clearly, a case study approach was chosen and the data were obtained from historical maps, aerial photos, urban development plans and newspapers. The main finding is that the increase in urban populations and the spread of urban land use have reshaped and destroyed the river landscape of the city of Kayseri. This study showed that a river, which plays a critical role in urban history, is a non-renewable resource.

Keywords: Heritage, Kayseri (Caiseria), Riverscape, Urban environmental history, Urban expansion.

\section{Introduction}

In the long history of humans, interrelations with waters and rivers have played an important role in human development and the emergence of human society, in the formation of early settlements and city development all over the world. The city was born "in between rivers", as in Mesopotamia, on the banks of the rivers Nile, Indus etc., throughout history. The growth of society continued along the river edge and the river was the most important means of transportation for domestic purposes and trade. Most cities tended to be founded beside or near rivers, along the river course, at the river mouth, the meeting of two rivers, sharp bends, or on islands (Kostof 1992: 39).

The long history of extensive human interventions in rivers shows that the relationship between the city and the natural environment has been a circular

*Assistant Professor, Erciyes University, Faculty of Architecture, Department of City and Regional Planning, Turkey. 
one. While the natural environment has profoundly shaped urban configurations, cities have a massive impact on the natural environment. Human activities and the pressures of society on the landscape are very changeable and landscapes can alter very quickly in terms of their features and landscape patterns. For example, urban developers have often reshaped natural environment by levelling hills, filling valleys and wetlands, and creating huge areas of made land. They have constructed a built environment of paved streets, malls, houses, factories, office buildings, etc., and altered urban riverscapes according to human needs, aesthetic ideals and technical options.

Before the $17^{\text {th }}$ century, rivers providing water resources for daily uses and trading operations were a primary criterion for city development. In the $19^{\text {th }}$ century, rivers were transformed into a focal point for business activities as well as for small settlements which developed into towns, while buildings were erected along the river for trade and industrialisation. After the 1970s, better means of transportation, which provided easier access, resulted in the river's decline as a form of communication. Moreover, since 1990, cities have turned their backs on rivers. Thus, historical buildings and traditional settlements, "worn-out industrial activities and a redundant transportation infrastructure" remain along the riverfront and the river in turn has become neglected (Hussein 2006). The rehabilitation of rivers is the most recent step in the long history of human interrelations with waters. The emergence of environmental issues and the concept of sustainability (Bruntland 1987) have highlighted new themes ${ }^{1}$. The old industrial areas along the rivers are now seen as an opportunity to improve leisure activities, and the quality and aesthetic appeal of public spaces have clear effects on tourism, and also implicitly on the economic development of cities.

According to the long history of human interrelations with waters, it is clear that cities and rivers are "socio-natural sites" - in Winiwarter and Schmid's terms (2008) - in which nature, society and culture are merged. Every region, city and town is characterised by its location, vegetation, buildings and infrastructure. From this perspective, it is possible to consider "cities as elements of fluvial landscapes" (Cities and Rivers 2012). While the elements of landscapes include "large-scale characteristics such as spatial relations and views as well as individual features including topography, vegetation, water feature, roads and paths, structure, site furnishings and objects" (Open Space Plan 2003), cultural landscapes are composed of a variety of features defining the historic character (Lipský and Romportl 2007). The term "cultural landscape" characterises the distinctive interrelationships between nature and people (Meeus 1995). Hence, the present cultural landscapes of urban areas are a product of long-term interactions between natural and cultural forces.

A great variety of regional and urban landscapes within Anatolian cities have been developed and created as a result of the long-term interactions between nature and culture. Many of the disturbing anthropogenic pressures have caused big or small changes on the cultural landscape. The protection of

${ }^{1}$ Like waterfront rehabilitation, water quality improvement and the regeneration of riversides, the restoration and (re)naturalization of rivers and streams, and the quality of urban landscape. 
heritage, such as individual buildings and monuments or an entire district or town, is rarely a problem because of the existing legislation. However, there is no restriction about the alteration of the urban riverscape. Kundzewicz and Samuels (1997) proposed that the approach of living with floods seems more sustainable than the historic approach of combating floods. Therefore every transformation of floodplains deserves careful consideration. Tacha (American Society of Landscape Architects 1991) states that "until water becomes as sacred, throughout the world as it is in India; we will not develop a proper riverfront solution". Hence, the most pressing problem is how easily a city's riverscape, which is a historical resource, can be changed.

The aim of this study, therefore, is to assess the relation of integration between a city and its river, and to describe the loss of the riverscape, which is a part of the cultural landscape, due to urban expansion in an Anatolian city. This paper concentrates on the case of Kayseri and the rivers around the city, a thoroughly representative example of the issues. The period of reference 1882-2012- covers the first drawn historical urban map of the city and the transformation of urban pattern.

The study is based on a combination of methods derived from urban development and urban environmental history. Data and evidence were collected by the use of two methods, namely literature surveys and case study. The data were obtained from historical maps, aerial photos, urban development plans and newspapers. Data collections from literature reviews were found from recommended books, journals and research reports, Masters and $\mathrm{PhD}$ Theses. Other important information was obtained by searching through Ottoman archives and also other library collections in Turkey for maps, urban plans, and cartographies.

The study is divided into three principal sections. The first section describes the city of Kayseri and its water resources and riverscapes. The second section depicts the situation of urban development and the disturbances and also the changes in Kayseri according to the planning periods. The last section gives the reasons for manipulating the rivers in Kayseri.

\section{Case Study of Kayseri}

The province of Kayseri is located on the Upper Kiz1lirmak River, also known as the "Halys River" region (Figure 1). The central city of the province, Kayseri, is a medium-sized, industrialised city in Central Anatolia. Being an Anatolian Tiger (European Stability Initiative 2005), the city is often cited in the first ranks among Turkey's cities. The city of Kayseri, as defined by the boundaries of the Kayseri Metropolitan Municipality, is structurally composed of five metropolitan districts called Melikgazi, Kocasinan, Hacilar, Talas, and Incesu. 
Figure 1. Location of Kayseri Province

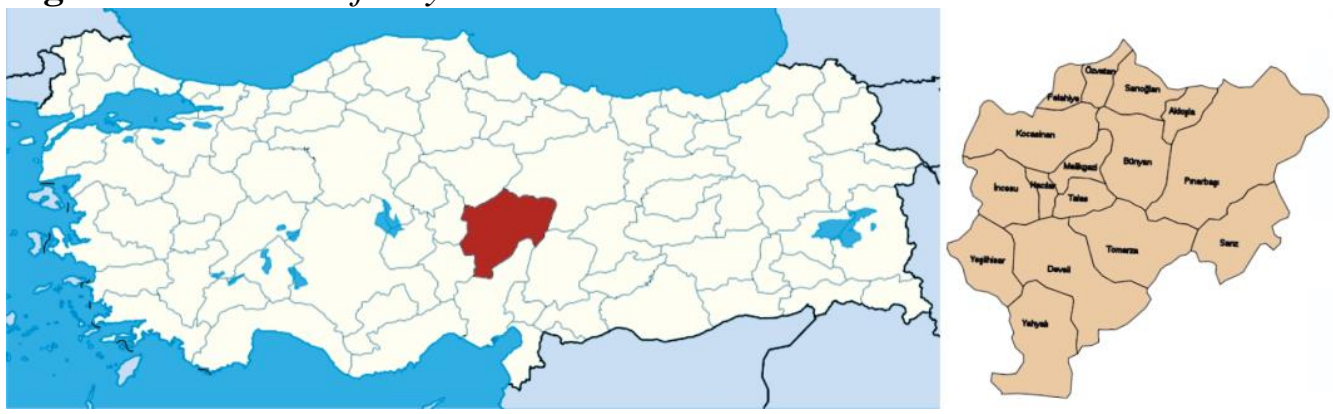

Source: Kayseri Metropolitan Municipality Archive.

\section{Geographical Situation of the City of Kayseri}

The province of Kayseri is situated on the northern part where the southern side of the Central Anatolia Mountains and the Taurus Mountains approach to each other. As if in two lines and parallel to each other, these high mountains are aligned from the southwest to the northeast. There are many plains and plateaus between these mountain chains.

Figure 2. The City of Kayseri

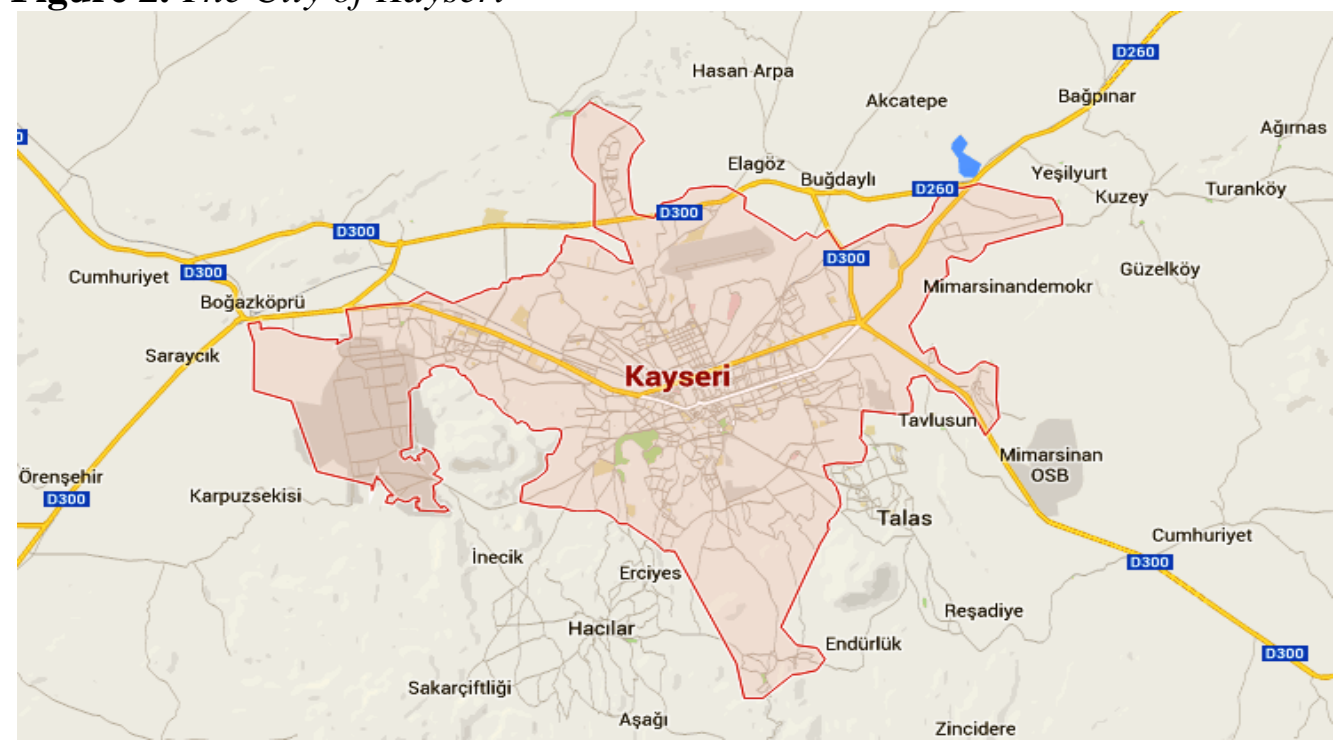

Source: Kayseri Metropolitan Municipality Archive.

Kayseri is located at the northern foot of Mount Erciyes which is only 30 minutes' drive from the city centre (Figure 2). The extinct volcano Mount Erciyes, which towers 3,917 metres high, rises alone in the centre of the plain, in the Central Anatolian Region (Figure 3). The lava expelled during the eruption of the mountain has determined the present day structure of the slopes and plateaus in the vicinity of Mount Erciyes. As a symbol of the city, Mount Erciyes, which is a notable trekking area and also a ski centre in winter, has become an important recreation and tourism area for the people of Kayseri. At the western side of Mount Erciyes, the Sultan Sazlığ National Preservation Area provides a natural habitat for 295 bird species (Wikipedia 2014). 
Figure 3. Mount Erciyes in Kayseri

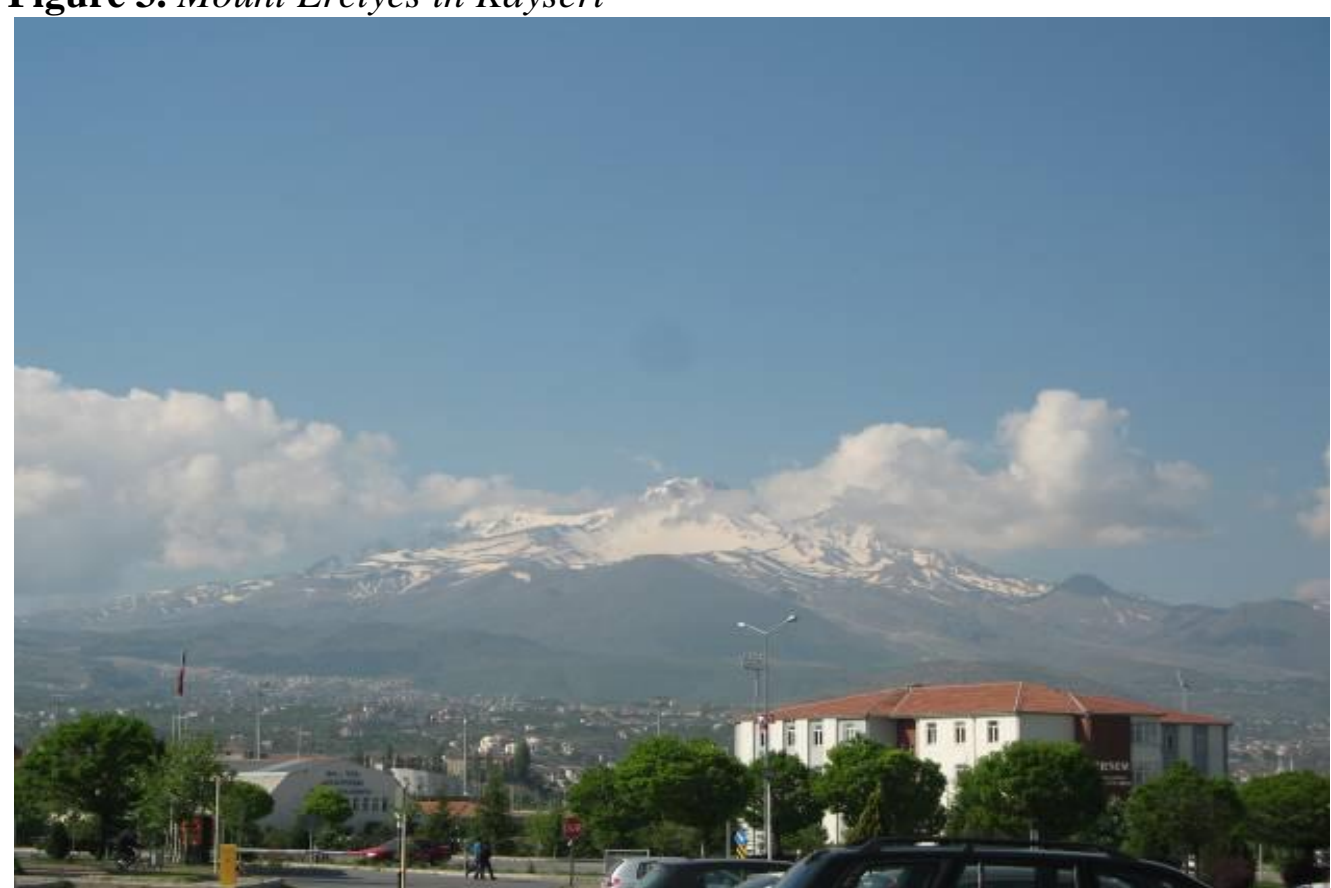

Source: By author.

\section{Water Resources of the City}

The city of Kayseri, which is located between two mountain chains and bordered to the north and west by an extensive lava plateau, is surrounded by river basins, named the Kizilırmak and Seyhan (Figure 4). The most important existing rivers in the province are the Kizılırmak River and the Sarımsaklı River. Approximately $128 \mathrm{~km}$ of the Kizilırmak River, which is the longest river within Turkey, passes through the province of Kayseri. The Kizilirmak River, collecting flows dropped to the north-western side of the city, streams down from the northeast towards the southwest. The Sarımsaklı River passes through the plain of Kayseri. The Karasu River and Delisu River are the other branches of the Kizilırmak River (Göde 2011). After the Sarımsaklı dam was constructed in the town of Bünyan, the Sarımsaklı River flows to the Boğazköprü Bridge by streaming down from the northern side of the city towards the western side and joins the Karasu River and the Kizılırmak River near the village of Beğdeğirmeni. On the other hand, the Zamantı River collects streams coming from the eastern side of the province. In addition, the Sultan Sazlığ National Preservation Area, a closed river basin, collects streams which flow down from the southern slopes of Mount Erciyes. 
Figure 4. Klzllırmak River and Branches of the Klzllırmak River in Kayseri Province

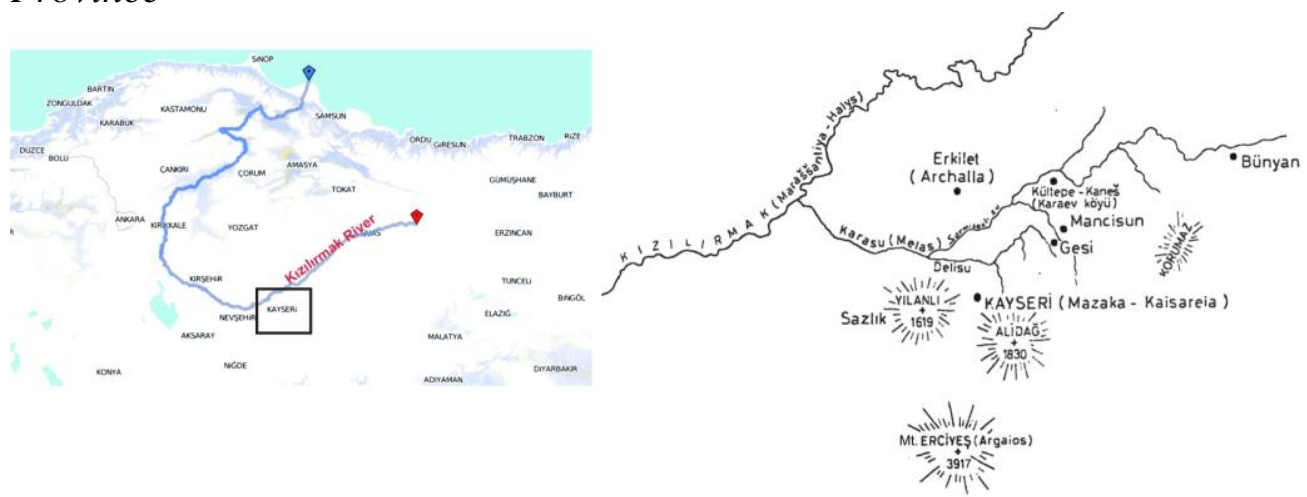

Source: Wikipedia 2015 \& Narin 1997.

Some small watercourses descend to the city from Mt. Erciyes and Mt. Ali. Although active in spring time, the beds of these watercourses are dry in the summer as a result of high weather temperatures (Figure 4). According to historians and geographers, many rivers and creeks flowed throughout the city and also irrigated the agricultural lands of the villages around the city. According to Özdoğan, (1948: 13-14) there were three major rivers called the "Pervane Suyu", "Göz Suyu", and "Hisarcık Suyu". The "Pervane Suyu", originating from the village of Horsana which is $10 \mathrm{~km}$ distant from the city, was used for irrigating a wide fertile agricultural area named "Pervane Suyu". Similarly the "Göz Suyu", whose source was in an area close to the village of Tavlusun ${ }^{1}$, was used to irrigate an area of fertile agricultural land named "Kavak Yazısı". The "Hisarcık Suyu", arising from the plateau of Tekir on Mt. Erciyes, availed irrigation of the vineyards and orchards around the city and country settlements. The name of the Delisu River was defined as "Huand Avgunlu Kömlikleri" on a historical map of the city from 1917. Therefore, the Delisu River and "Pervane Suyu" were the names used at different ages for the same river.

\section{Riverscape of the City}

As a result of climatic conditions and the influence of tradition, it is a common practice for people in Kayseri to use vineyard and orchard houses in summer season (İmamoğlu 1996). Therefore, the slopes of the hills around the city -at the foot of Mount Erciyes and at the back of Erkilet Hill in the northare full of summer houses which are used seasonally between June and September. Almost all summer houses have cisterns and tanks. The historical literature of the city written by many travellers and also historians describes this unique pattern of urban life. Furthermore, historians describe the riverscape of the city. For example, Ebulfeda (cited in Gabriel 1931: 70) states that Kayseri had plenty of watercourses, rivers, fruits, orchards, and trees during the $14^{\text {th }}$ century.

\footnotetext{
${ }^{1}$ Nowadays, Tavlusun is a neighborhood of Kayseri metropolitan city.
} 
In the $17^{\text {th }}$ century, Hac1 Kalfa (cited in Gabriel 1931: 71) explained that there were plentiful rivers, vineyards and orchards around the city of Kayseri. Similarly, an Ottoman traveller of the $17^{\text {th }}$ century, Çelebi (1970), who travelled throughout the Ottoman Empire says there was a moat surrounding the citadel of Kayseri which normally filled with water in winter, and was planted with vegetables in spring (Figure 5a). He also gives detailed information on the bridges and the rivers flowing into the Kizilırmak River by passing through the city. As to Inciciyan (cited in Akşit 1998: 37), the water in the moat, which had removable bridges over it, originates from Talas County. Çelebi (1970) also gives an account of Tekgöz Bridge (Figure 5b), which was constructed by the leading Ottoman architect Mimar Sinan during the $16^{\text {th }}$ century, over the Kizılırmak River some distance from the city.

Figure 5a. The Citadel and the Wooden Bridge on the Moat

Figure 5b. Tekgöz Bridge over the Kizllırmak River

Figure 5c. Riverine Landscape of Delisu River at the Northern Side of the City Next to the Train Station, at the beginning of the $20^{\text {th }}$ Century
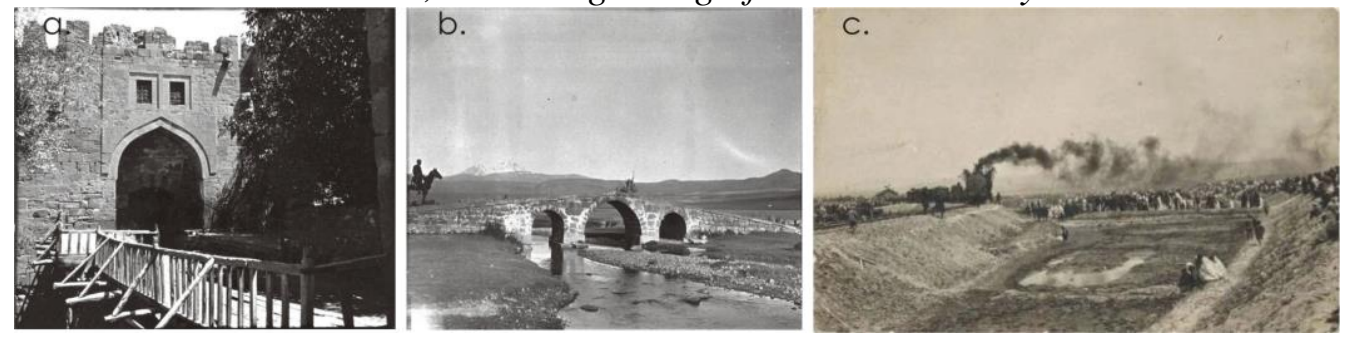

Source: Bell 1909.

One of the more enlightening accounts is Türkten's (1996: 351) detailed description of the eastern side of city and the Delisu River. He wrote that "one can enter from Sivas Avenue at the eastern side of the city, by passing over the bridge over the Delisu River which descended from the counties of Hisarclk and Kiranard into the city. The Delisu River conveyed floods occurring with strong rain and snowmelt to the Sartmsakl River in the spring, called the "Avgun (stone wells)" among the people. After crossing the bridge, there was a road beside the river leading towards the neighbourhood of Gültepe also a housing district, right on the road". Thus, the Delisu River is more important than the other rivers of the city (Figure 5c). 
Figure 6. Historical Development of the Rivers Prior to Channelisation, 1882, 1917,1931

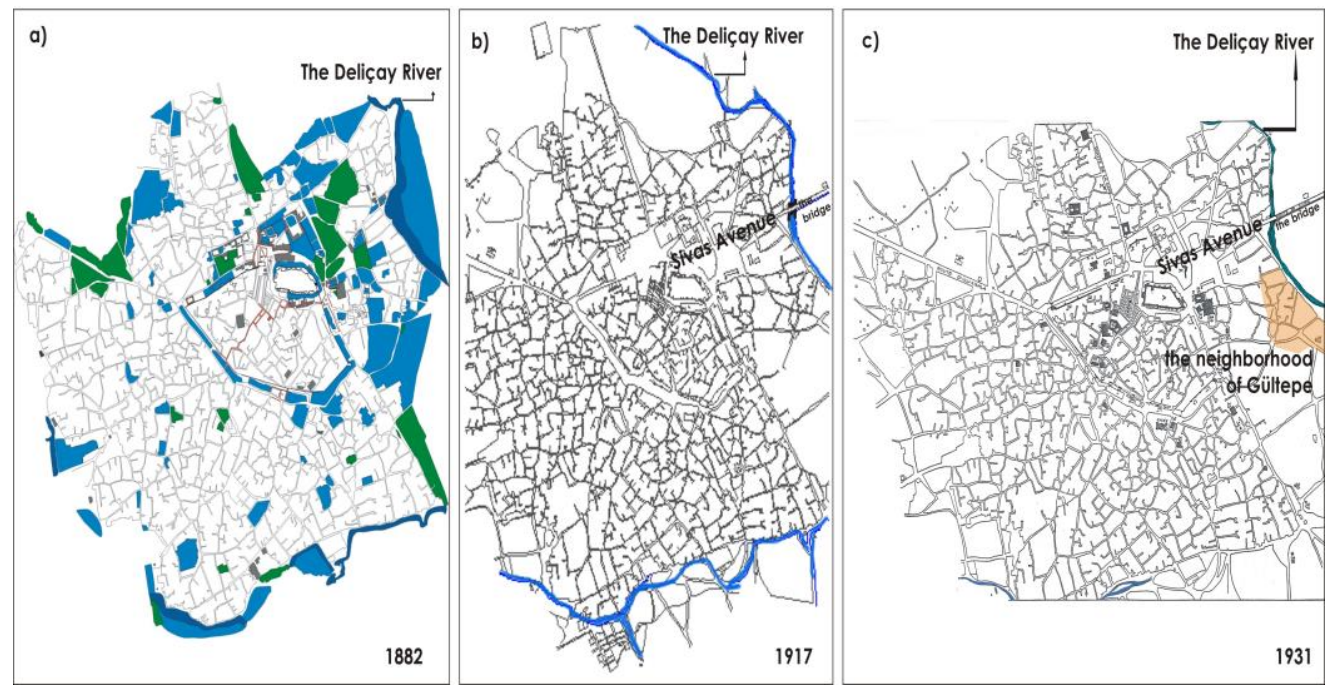

Source: Gabriel 1931.

While the historical sources do not provide a clear picture, an environmental history of the rivers within the city of Kayseri could start with Matrakçı Nasuh's miniature. Despite being an inaccurate map of the time, and inappropriate for georeferencing, it was the first one to depict the city and its environs, namely the county of Incesu and Yeşilhisar, during the $16^{\text {th }}$ century. Although the historians give an extensive summary of the history of rivers, creeks and watercourses and describe the riverscape, we have no illustrative information on the previous riverbed of the Delisu River and its riverfront even though there were several maps clearly showing them. However, there are several street and city maps which support these depictions of the riverscape. One of these was a map of 1882 drawn by Jean S. Euthychides, and the others were city maps of 1917 and 1931 which were used in Albert Gabriel's (1931: 16) drawings. All the maps demonstrated the city plan and the rivers' natural alignment (Figure 6).

\section{Urban Development Periods}

The city-river relationship can be examined in four different periods. These are as follows: i) the integration period between 1882 and 1945; ii) the decline of rivers period between 1945 and 1975; iii) the uncontrolled and widespread urban expansion period between 1975 and 2005; and iv) the urban river rehabilitation period between 2005 and 2012.

The Integration of City and River: 1882

According to the urban map of 1882 the limits of the eastern side of the city end at the Delisu River (Figure 7). It also shows that the city was surrounded by rivers and creeks at the southern and western sides. However, 
the most important one was the Delisu River, when it is compared with the others in terms of their river beds. An interesting aspect of the urban landscape was that there was no housing area on the opposite bank of the rivers. Consequently, the macro form of the city constituted a compact square shaped settlement at the end of the $19^{\text {th }}$ century.

Figure 7. Urban Map of Kayseri, 1882

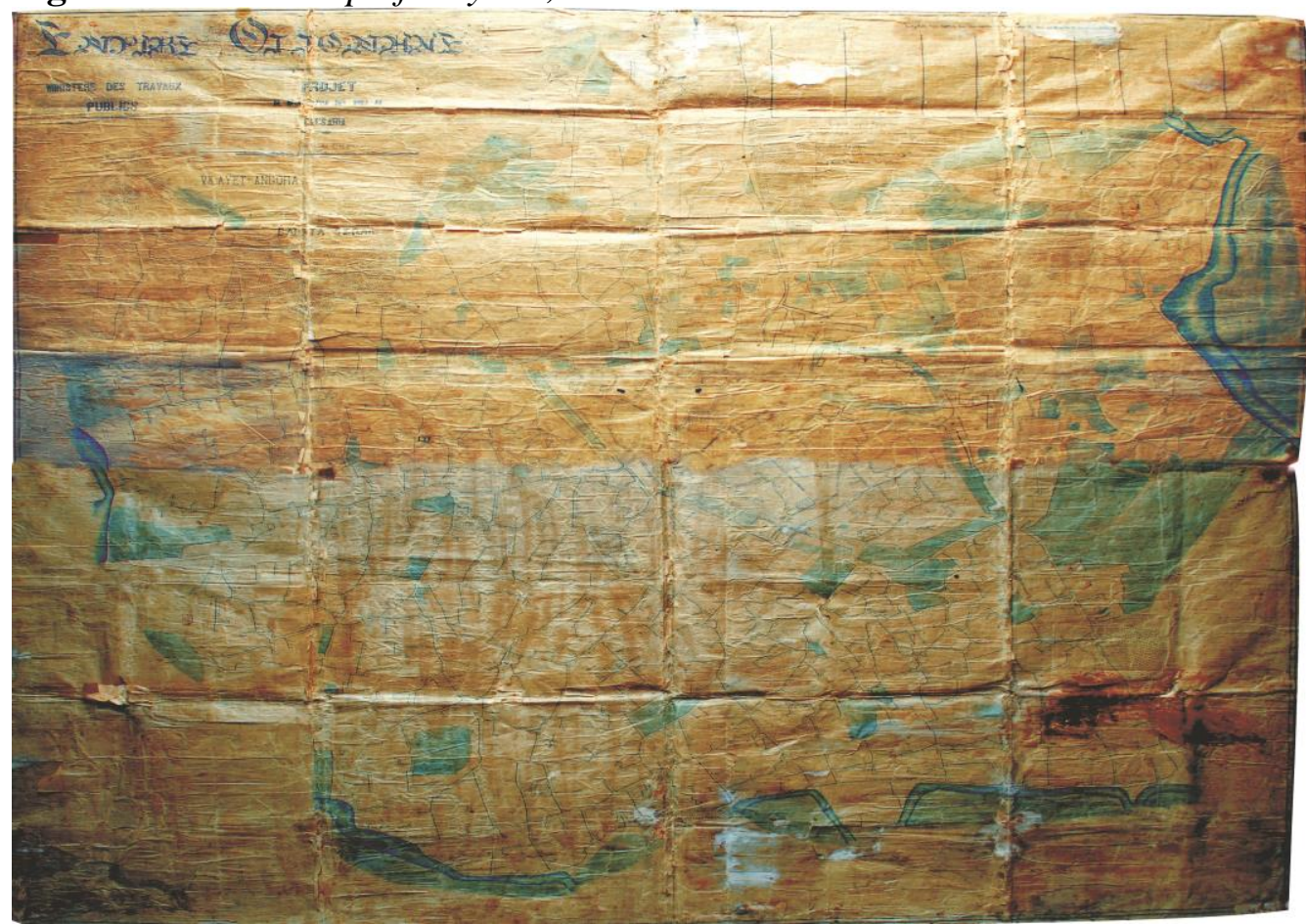

Source: Municipality Archive.

The first attempt around 1920 was to close off the southern river basin. The next intervention, undertaken in the 1930s, was aimed at controlling the river bed and opening Sivas Avenue at the eastern side of the city, and also constructing a bridge over the river. However, the bridges on the Delisu, Karasu and Kizılırmak rivers made a comfortable connection from the city to other areas located at the northern, western and eastern sides.

\section{The Rivers' Decline: 1945}

Although the limits of the traditional city of Kayseri remained the same until the 1930s, with the construction of the first industrial areas and infrastructural investments, the need for new development areas to accommodate the growing population arose. Under these circumstances, a master plan of Kayseri, which took into consideration the principles of modern urbanism, began to be prepared in 1944 and was finalised in 1945 (Figure 8). The development plan did not aim to conserve the historical buildings, except for some monumental buildings, mosques, schools, baths, tombs and a few of the traditional houses of Kayseri. The transformation and devastating process began at first in the city's commercial centre beginning from the traditional 
bazaar and castle. The most striking thing about the plan is its culverts, channelled river sections under the infrastructure, and also bank and bed stabilization. As a matter of fact, this alteration can be clearly seen on the urban map and also on aerial photographs. While the Delisu River's bank and bed were stabilized, the other small watercourses surrounding the city were diverted into the culverts.

Figure 8. Master Plan of Kayseri, 1945

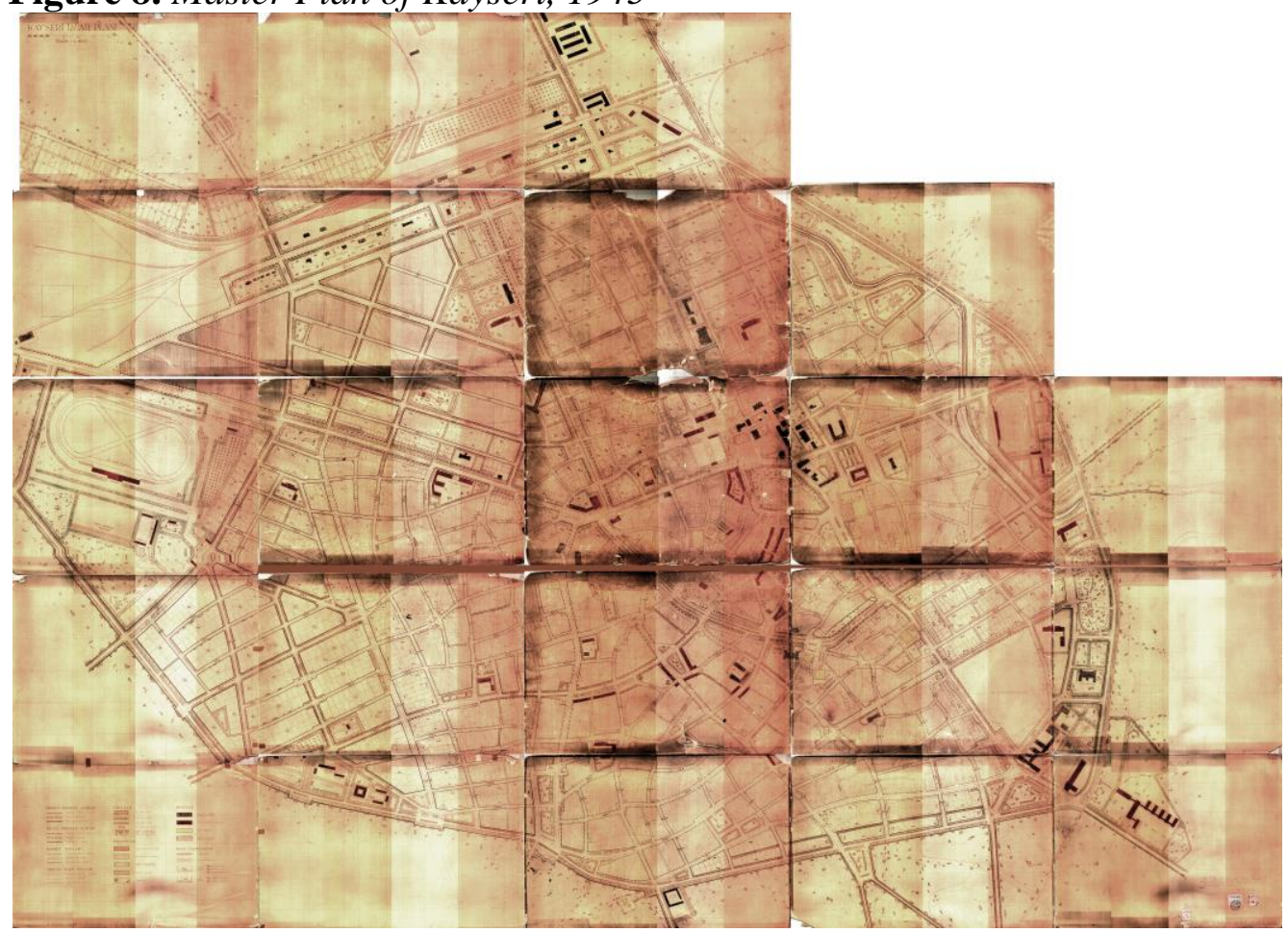

Source: Municipality Archive.

The Age of Urban Expansion: 1975

Although on urban preservation site was legally announced, the conservation decisions did not provide adequate conditions for the survival of historical buildings. The historical settlement pattern and traditional housing features started to disappear. In addition, the historical trade centre was transformed into a modern city business centre. New housing development areas were set at the west and east sides of the city which were closely connected with the main transportation routes, Istanbul and Sivas Avenues. Therefore, the city's compact form was converted into a linear form. 
Figure 9. Master Plan of Kayseri, 1975

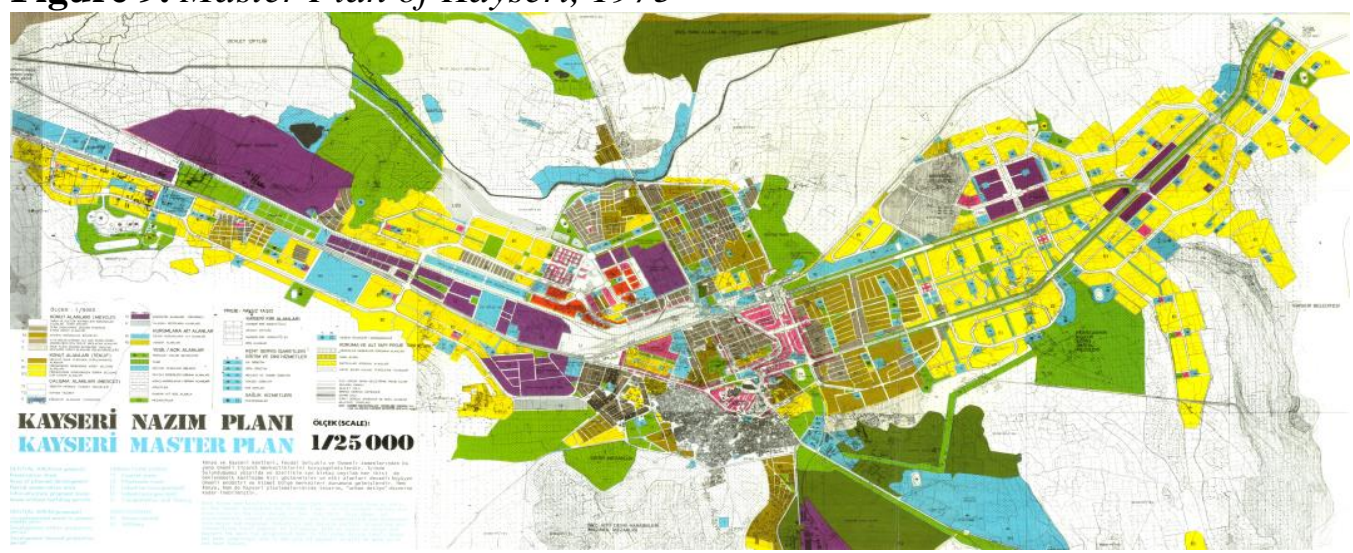

Source: Municipality Archive.

The development plan suggested constructing broad boulevards and highrise buildings, which are still a characteristic feature of Kayseri city (Figure 9). Considering the nonexistence of green areas and trees inside and around the city, the plan proposed to use orchards and vineyards situated on the south foothills, in the small towns named Hacilar, Hisarcik and Talas as the landscape area of the city. In this period, major manipulations of rivers, particularly the Delisu River, took place. The Delisu River's bank and bed disappeared within the city. The limits of the city were extended to the frontiers of the Sarımsaklı River whose bank and bed were stabilized at the northwestern side.

Figure 10. Master Plan of Kayseri, 1986

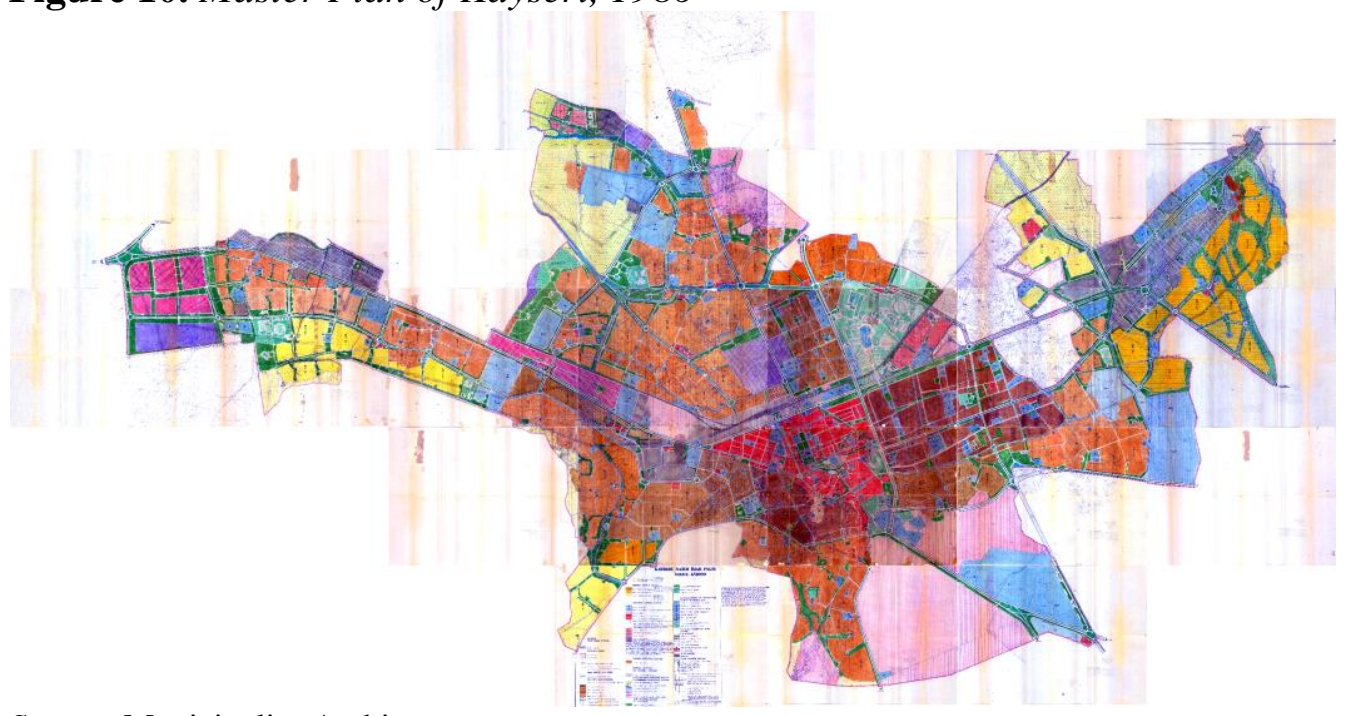

Source: Municipality Archive.

In the 1980s, the limits of the city were extended to the small town of Talas, which is located in the south of Kayseri. On the other hand, the historical city of Kayseri was eliminated. After 1985, the city population was greater than the rural population. As a result, the city gained metropolitan 
municipality status in 1988. In 1986, a new master development plan was prepared (Figure 10). Accordingly, high-rise buildings and housing projects for middle and upper income groups increased and the use of new materials and techniques was similar to that of the previous period.

The manipulations of the rivers remained the same as before. As a result, bank and bed stabilization, river canalisation and spatial constraints from adjacent housing were still the main approach to the river frontiers and stream alignment.

\section{Rehabilitation of Urban Rivers: 2005}

In 2006, due to the expansion of hinterland, the boundary of the metropolitan municipality was changed and absorbed many small towns. As a result, a new metropolitan master plan was needed (Figure 11). The main themes which were determined in previous development periods were still valid for this development plan. However, these decisions resulted in urban sprawl.

Figure 11. Master Plan of Kayseri, 2006

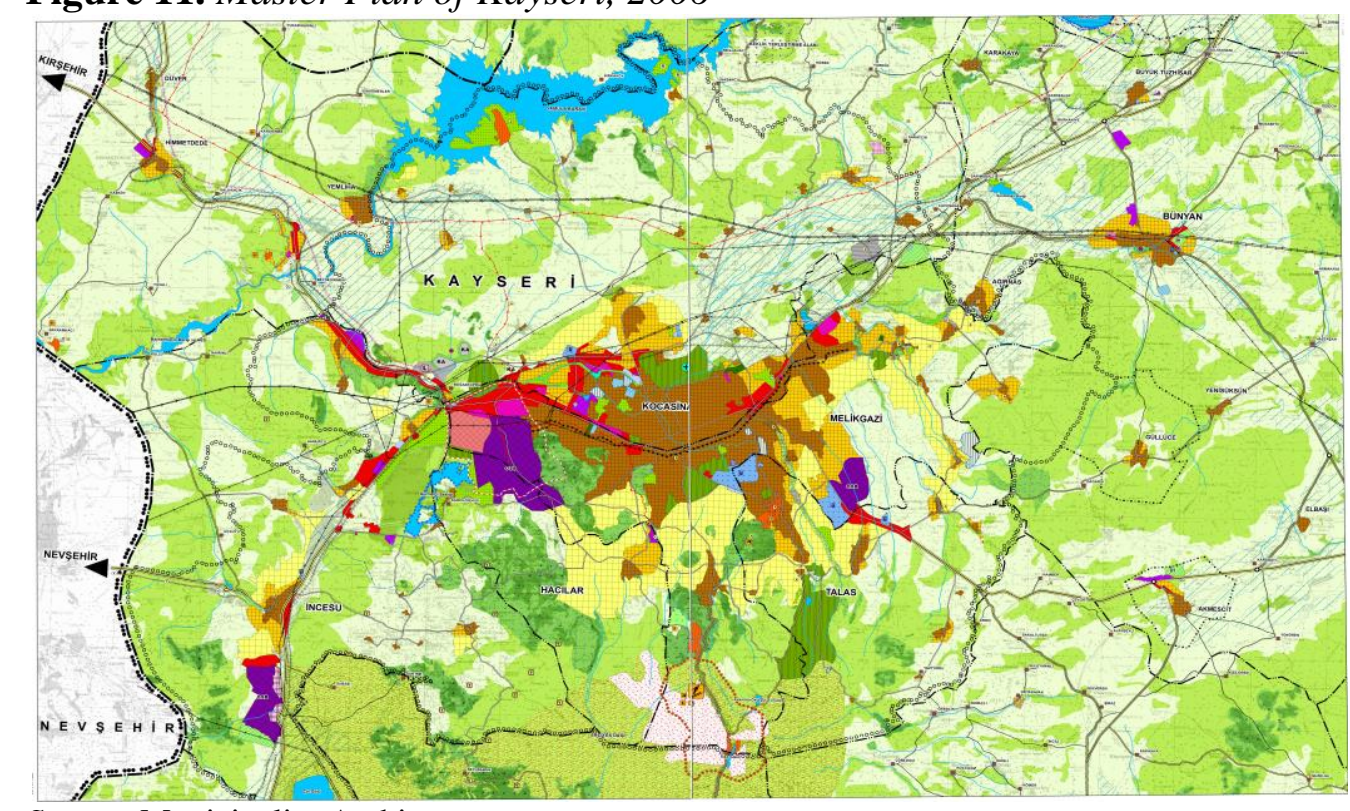

Source: Municipality Archive.

In the 2000s local governors, in particular the mayor of the Metropolitan Municipality of Kayseri, tried to make Kayseri a model city. In order to make this vision succeed a variety of projects were prepared by the municipality. One of the mega projects is the "Channel Project of Kayseri", which propose the building of an artificial river bed and bank stabilization, an artificial environment, stream development and bringing water from the Kız1lırmak River into the city. In this project conducted in collaboration with the Government's Water Affairs Ministry, it is hoped to transform and rehabilitate the rivers and creeks. 
Figure 12. Illustrations of the Mega Project of "Sea City"

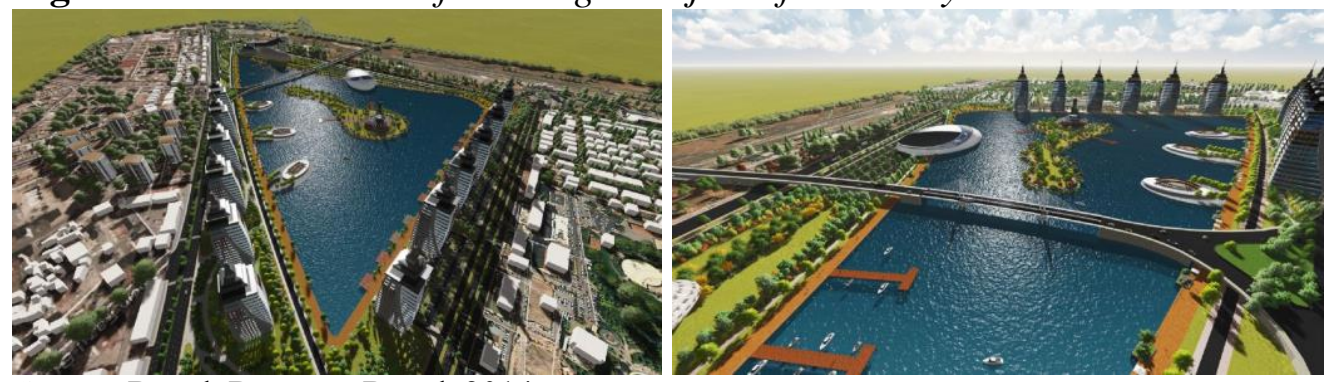

Source: Büyük Düşünüp Büyük 2014.

The other project called "Sea City - Şehr-i Derya", was announced in 2014 by the municipality of Kayseri before the municipality elections of March 2014. The project proposes to transform the old industrial area located in the city and build a mixed use area involving housing and recreation areas, and a commercial centre. In addition, it suggests creating an artificial lake by using water from the Kizilırmak River and also generating a green recreational region surrounding the area (Figure 12). However, neither the Channel Project of Kayseri, nor the "Sea City Project" are proposals of the city's valid master plan of 2006.

\section{Findings}

To the city of Kayseri, rivers were always a territorial discontinuity, a physical barrier. One can identify a number of typical pressures on urban rivers that result from anthropogenic activities. Anthropogenic pressures appear to have grown relentlessly from the 1930s and even later in Kayseri. The increase in urban populations and the spread of urban land use have reshaped and destroyed the river landscape of the city of Kayseri. For the Delisu River, the findings show that steam navigation on the river started in the 1830s. Due to a lack of sensitivity and understanding about the city's relation with nature, rivers were abused and neglected.

One driving force dominates the creeks, rivers and their further transformation: flood protection. The morphological features of urban rivers in Kayseri have often been heavily altered in densely used urban spaces and there were spatial constraints on urban water courses. Therefore, the urban demand for space and security of land use resulted in culvert sections under the infrastructure, bank and bed stabilization and flood control dams. These alterations have led to a dramatically disrupted ecological integrity and have resulted in a loss of historical memory.

A series of reconstructions clearly shows the difference between a largely natural river at the beginning of the period and a channelled, dammed canal in 1945. This series, seen in Figure 13, involved the manipulation of the rivers beginning in 1882 , the time for which the earliest accurate map is available. The most visible difference resulting from the interventions into the rivers is 
Vol. 1, No. $2 \quad$ Coteli: Urban Environmental History of an Anatolian City...

that the city's compact urban form was converted into a linear form; also, the riverscape of Kayseri was destroyed.

Figure 13. Series of Manipulations on Delisu River
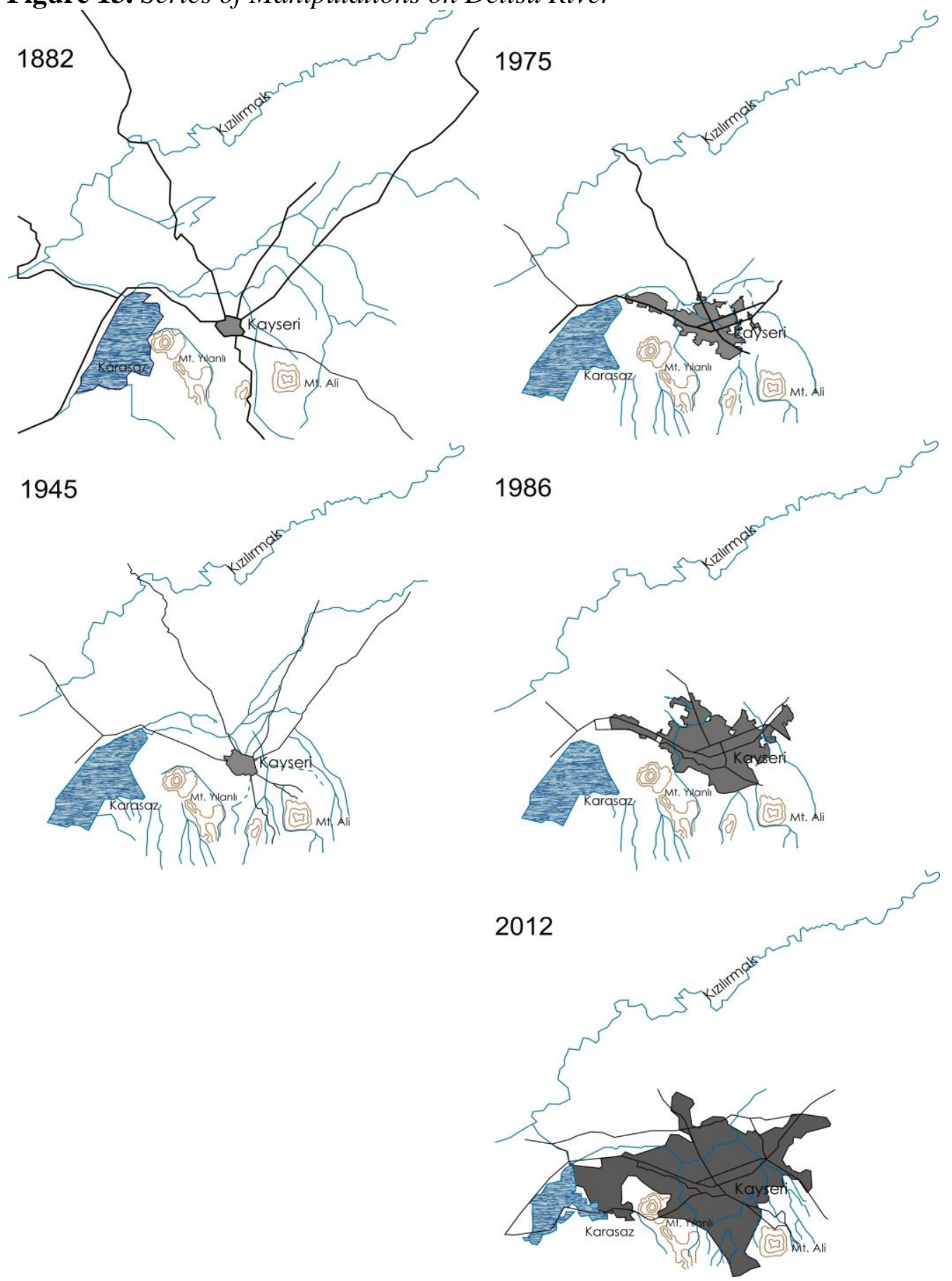

Source: By author.

In addition, the proposed mega rehabilitation projects will result in further morphological change in the Delisu River's basin and create denaturalized stream alignments and gradients. Two laws direct the rehabilitation of 
watercourses in urban areas in Turkey. Firstly, the "Metropolitan Municipality Law No. 5216" (Büyükşehir Belediyesi Kanunu 2004) gives responsibility for waterfront rehabilitation and the regeneration of riversides and the restoration and (re)naturalization of rivers and streams to municipal authorities. However, these laws do not include any guide about the methodology of landscape preservation. Secondly, "The Notice of Prime Ministry No. 2010/5" concerning the improvement of rivers and streams gives the implementation responsibility to municipalities and the design of the projects to the Government's Water Affairs Ministry. The case of Kayseri shows that the restoration of the urban riverscape is being considered for reasons such as tourism, trade, and recreation, instead of the environment (Büyükşehir Belediyesi Kanunu 2004, Akarsu ve Dere Yataklarının Islahı ile İlgili 2010/5 2010).

Due to the lack of urban settlement on the opposite bank of the river, and its bordering the city on more sides, the position of the river relative to the city was tangible until 1945. After that, river navigation was continuously transformed and the intervention of channelization is the only relation with the river. Beginning from 1945 to the 1970s, the city-river relation changed to an eccentric position. However, from the 1970s built areas on both banks were spread out towards both the eastern and western sides. Hence, the relation between the river and city changed again into a diametric position. Nevertheless, there is no visual or physical contact with water in Kayseri city.

\section{Conclusions}

A river, which has a critical role in urban history, is a non-renewable resource. Despite their being a part of cultural landscape and serving to maintain our connection with the past, rivers are one of the fast-changing landscape elements. Urban rivers are manipulated parts of the urban infrastructure of Anatolian cities.

From the analysis of the results it becomes clear that there is at present no legislation related to the landscape character which does not decrease the aesthetic and natural value of landscape. It is obvious that there is a deep legal void which was left in the hands of local governors. For this reason, it is necessary to produce legislation on the rehabilitation of rivers and creeks. In addition, the restoration of urban rivers should be conducted according to their historical form. Otherwise, making any changes in alignment and generating a uniform urban river will have low aesthetical value.

The analysis of the environmental history of a city and river should take into consideration variables linked to urban expansion and to the river bed. Rivers are not expendable urban resources and cannot be dissociated from the city they run through. Consequently, urban development plans should not be designed to divert rivers which are the product of long-term interactions between natural and cultural forces. 


\section{Acknowledgements}

This study is part of a continuous research named "An Urban Environmental History of Anatolian Cities" and was presented at the $4^{\text {th }}$ Annual International Conference on Urban Studies and Planning in June 2014, Athens, Greece. I would like to thank Şükrü Karatepe from Yıldırım Beyazıt University, Alemdar Ünlü from the Water and Sewage Company of Kayseri, Esat O $\breve{g} u z$ Edin from the Government's Water Affairs Ministry and Filiz Sönmez from Erciyes University for their support.

\section{References}

Akarsu ve Dere Yataklarının Islahı ile İlgili 2010/5 Sayılı Başbakanlık Genelgesi [The Notice of Prime Ministry No: 2010/5 related to rehabilitation of river beds and creeks] (2010). [Online] Available from: http://www.resmi-gazete.org/rega/akar su-ve-dere-yataklarinin-islahi-ile-ilgili-2010-5-sayili-basbakanlik-genelgesi1283.htm. [Assessed: 30 August 2014].

Akşit A (1998) Selçuklular Devrinde Kayseri Şehrinin Fiziki Yapısı [The Physical Structure of Kayseri City in Seljuk Period]. In: Aktan A and Öztürk A (ed.) II. Kayseri ve Yöresi Tarih Sempozyumu Bildiriler Kitabu $\left[2^{\text {nd }}\right.$ Local History of Kayseri Symposium Proceedings]. Kayseri: Erciyes Üniversitesi Kayseri ve Yöresi Tarih Araştırmaları Merkezi Yayınları, 35-45.

American Society of Landscape Architects (1991) Landscape Architecture. American Society of Landscape Architects, 168.

Bell (1909) Near Caesarea-Turkey. [Online] Available from: http://www.gerty.ncl.ac. uk/search photos results.php?search photos=kayser\&Submit=Search+photos. [Accessed: 10 March 2015].

Bruntland G (1987) Our Common Future: Report of the World Commission on Environment and Development. Oxford: Oxford University Press.

Büyük Düşünüp Büyük İs Yapmalıyı [We Have to Think Bigger and Do Bigger Things] (2014). [Online] Available from: http://mehmetozhaseki.com/haber.asp? $\mathrm{id}=263$. [Accessed: 13 May 2014].

Büyü̈şehir Belediyesi Kanunu [Metropolitan Municipality Law] (2004). [Online] Available from: http://www.tbmm.gov.tr/kanunlar/k5216.html. [Accessed: 7 May 2015].

Çelebi (1970) Seyahatname [The Seyahatname]. İstanbul: Üç Dal Neşriyat.

Cities and Rivers-Long Term Development of Socio-Natural Sites (2012). [Online] Available from: http://www.eauh2014.fcsh.unl.pt/index.php?conference=confere nce\&schedConf $=$ eauh2014\&page $=$ schedConf\&op=trackPolicies. [Accessed: 26 June 2012].

European Stability Initiative (2005) Islamic Calvinists, Change and Conservatism in Central Anatolia. [Online] Available from: http://www.esiweb.org/pdf/esi docu ment_id_69.pdf. [Accessed: 03 July 2014].

Gabriel A (1931) Monuments Turcs d'Anatolie: Kayseri - Niğde [Anatolian Turks Monuments: Kayseri - Niğde]. Paris: E. de Boccard.

Göde K (2011) Halil Edhem (Eldem) ve Kayseri Şehri-Selçuklu Tarihinden Bir Bölüm [Halil Edhem (Eldem) and the City of Kayseri-A Section of Seljuk's History]. Kayseri Büyükşehir Belediyesi Kültür Yayınları. 
Hussein H (2006) Urban recreational riverfronts: successful revitalisation elements. Journal of Design and the Built Environment 2(1): 1-14.

İmamoğlu V (1996) Yüzyılın İlk Yarısında Kayseri Kenti: Fiziki Çevre ve Yaşam. In: I. Kayseri ve Yöresi Tarih Sempozyumu Bildiriler Kitabu $\left[1^{\text {st }}\right.$ Local History of Kayseri Symposium Proceedings. Kayseri: Erciyes Üniversitesi Kayseri ve Yöresi Tarih Araştırmaları Merkezi Yayını [Erciyes University, Kayseri and Local History Research Centre Publication], 119-128.

Kostof S (1992) The City Assembled: The Elements of Urban Form through History. London: Thames and Hudson Ltd, 39.

Kundzewicz Z and Samuels PG (1997) Conclusions of the $2^{\text {nd }}$ RIBAMOD Workshop and Expert Meeting. Luxembourg: European Commission DG XII.

Lipský Z, Romportl D (2007) Classification and Typology of Cultural Landscapes: Methods and Applications. In: The Role of Landscape Studies for Sustainable Development. Warsaw, Poland: University of Warsaw, 519-535.

Meeus J (1995) Landscapes. In: Stanners D and Bourdeau P (ed.) Europe's Environment. Copenhagen: The Dobřrǐs Assessment, European Environment Agency, 172-189.

Narin H (1997) Kayseri'de Yerleşmenin Evrimi [The Evolution of the Settlement in Kayseri]. PhD Thesis. Istanbul: Marmara University.

Open Space Plan-The City of Calgary Parks (2003). [Online] Available from: http://www.calgary.ca/CSPS/Parks/Documents/Planning-and-Operations/openspace-plan.pdf?noredirect=1. [Accessed: 29 June 2012].

Özdoğan K (1948) Kayseri Tarihi Kültür Ve Sanat Eserleri, Alimler-ŞairlerSanatkarlar [The History, Culture and Artistic Works of Kayseri, the ScholarsPoets-Artisans]. Kayseri: Erciyes Matbaas1.

Türkten N (1996) Kayseri'de Yanlış Şehirleşme ve Mahzurları [The Mistakes and Disadvantages of Urbanization in Kayseri]. In: I. Kayseri ve Yöresi Tarih Sempozyumu Bildiriler Kitabl $\left[1^{\text {st }}\right.$ Local History of Kayseri Symposium Proceedings]. Kayseri: Erciyes Üniversitesi Kayseri ve Yöresi Tarih Araştırmaları Merkezi Yayını [Erciyes University, Kayseri and Local History Research Centre Publication], 351-355.

Winiwarter V, Schmid M (2008) Umweltgeschichte als Untersuchung sozionaturaler Schauplätze? Ein Versuch, Johannes Colers Oeconomia umwelthistorisch zu interpretieren [Environmental history as a study of socio-natural scenes? An attempt to interpret John Colers historic/environmental economy]. In: Knopf T (ed.) Umweltverhalten in Geschichte und Gegenwart - Vergleichende Ansätze [Environmental Performance in History and in Present - Comparative Approaches]. Göttingen: Attempto, 158-173.

Wikipedia the Free Encyclopedia (2014) Kayseri. [Online] Available from: http://commons.wikimedia.org/wiki/Kayseri. [Accessed: 12 May 2014].

Wikipedia the Free Encyclopedia (2015) Kızılırmak Map. [Online] Available from: https://en.wikipedia.org/wiki/K\%C4\%B1z\%C4\%B11\%C4\%B1rmak_River\#/medi a/File:Kizilirmak-map.jpg. [Accessed: 12 May 2014]. 
